AperTO - Archivio Istituzionale Open Access dell'Università di Torino

Women, Work, and Politics: the Political Economy of Gender Inequality. by Torben Iversen and Frances Rosenbluth. New Haven: Yale University Press 2010

This is a pre print version of the following article:

Original Citation:

Availability:

This version is available http://hdl.handle.net/2318/97350

since 2017-05-26T16:22:17Z

Published version:

DOI:10.1080/13545701.2012.717176

Terms of use:

Open Access

Anyone can freely access the full text of works made available as "Open Access". Works made available under a Creative Commons license can be used according to the terms and conditions of said license. Use of all other works requires consent of the right holder (author or publisher) if not exempted from copyright protection by the applicable law. 
This article was downloaded by: [Universita degli Studi di Torino], [Maria Laura Di Tommaso]

On: 14 September 2012, At: 03:49

Publisher: Routledge

Informa Ltd Registered in England and Wales Registered Number: 1072954

Registered office: Mortimer House, 37-41 Mortimer Street, London W1T 3J H, UK

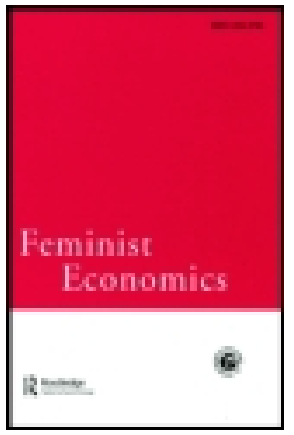

\title{
Feminist Economics
}

Publication details, including instructions for authors and subscription information:

http:// www. tandfonline.com/loi/ rfec20

\section{Women, Work, and Politics: The} Political Economy of Gender Inequality, by Torben Iversen and Frances Rosenbluth. New Haven: Yale University Press, 2010. 224 pp. ISBN-13: 9780300153101 (hbk.). US $\$ 35.00$.

\author{
Maria Laura Di Tommaso ${ }^{\text {a }}$ \\ a Department of Economics, University of Torino, Via \\ Po 53, Turin, 10100, Italy \\ Version of record first published: 04 Sep 2012.
}

To cite this article: Maria Laura Di Tommaso (2012): Women, Work, and Politics: The Political Economy of Gender Inequality, by Torben Iversen and Frances Rosenbluth. New Haven: Yale University Press, 2010. 224 pp. ISBN-13: 9780300153101 (hbk.). US\$35.00., Feminist Economics, DOI: 10.1080/ 13545701.2012.717176

To link to this article: http:// dx. doi.org/ 10.1080/ 13545701.2012.717176

\section{Girst}

PLEASE SCROLL DOWN FOR ARTICLE

Full terms and conditions of use: http://www.tandfonline.com/page/termsand-conditions 
This article may be used for research, teaching, and private study purposes. Any substantial or systematic reproduction, redistribution, reselling, loan, sublicensing, systematic supply, or distribution in any form to anyone is expressly forbidden.

The publisher does not give any warranty express or implied or make any representation that the contents will be complete or accurate or up to date. The accuracy of any instructions, formulae, and drug doses should be independently verified with primary sources. The publisher shall not be liable for any loss, actions, claims, proceedings, demand, or costs or damages whatsoever or howsoever caused arising directly or indirectly in connection with or arising out of the use of this material. 


\section{BOOK REVIEW}

Women, Work, and Politics: The Political Economy of Gender Inequality, by Torben Iversen and Frances Rosenbluth. New Haven: Yale University Press, 2010. 224 pp. ISBN-13: 9780300153101 (hbk.). US\$35.00.

I approached this book with some doubts because a book that promises "to integrate the micro-level of families with the macro-level of national institutions" seemed too ambitious not to be superficial and generic. I was wrong. From the very first chapter, I was taken by the powerful and empirically grounded arguments on which the authors rest their analysis. The authors examine why women in the developed world still lag behind men in the exercise of power in several fields. ${ }^{1}$ Following an introductory chapter that sets out a political economy approach to studying gender inequality, the book covers five topics in five main chapters: patriarchy, gender division of labor, fertility, political preferences, and political careers.

Iversen and Rosenbluth explore the complex relationships between decision-making processes at a household level, the gender division of paid and unpaid work, political power, fertility, economic modes of production, and economic development. In other words, they provide some insight into the different causal relationships between what happens at the micro level of the household and at the macro level of the economy.

The authors begin their analysis by explaining the origins of patriarchy in the productive structure of an economy. They argue that in huntergatherer societies, women were more powerful; in agricultural economies, the rigid division of gender roles within patriarchal systems became functional to production. Women regained power in the process of industrialization and have especially advanced in postindustrial societies in which the service sector is predominant. These are not new ideas, but Iversen and Rosenbluth explain these changes as a shift in the relative bargaining power among partners, resulting from the rise in women's outside options (the ability to walk away from a marriage) and entry into the labor market. Agricultural societies place a premium on men's brawn, 
and therefore women's employment is inefficient compared with men's employment. Industrialization and even more the rise of the service sector have transformed social values, providing viable alternatives to unsatisfying marriages.

Moreover, mate preferences vary accordingly in relation to the productive structure of the economy. Indeed, simulations of the effect of industrial and service employment on variables representing mate preferences (the importance attached to chastity, being a good cook and housekeeper, and having desire for home and children) show that these values are less important in industrial and postindustrial societies. ${ }^{2}$ The authors also link these phenomena to some features of the labor market, particularly the skills required. When the skills required on the labor market are mainly job specific, women's labor force participation is low because women have more career breaks and interruptions in their work lives and therefore they are unable to invest too much in job-specific skills. The more generic jobs and transferable skills are required in the labor market, the higher is women's labor force participation.

Iversen and Rosenbluth follow this with a discussion of the gender division of labor, which they also explain through the bargaining process within the household and the structure of the labor market. In a society with high divorce rates, it would be efficient for women to invest in the labor market and claim an equal division of work at home. So if outside options are equally attractive to both sides, the authors would predict an even distribution of household work. Nevertheless, both the rate of divorce and the structure of the labor market influence the outcomes in terms of division of labor: the higher the divorce rate, the higher the labor force participation, and vice versa. Nevertheless, women's participation in the labor market tends to be lower in economies with specific-skills labor markets; moreover, the distribution of household work tends to be more unequal in systems with generic-skills labor markets. For instance, Iversen and Rosenbluth argue that in the United States, a flexible labor market favors women's labor force participation and therefore a more equal division of housework. The rigid, dualistic, and unionized labor market in Italy prevents women from participating in the labor market and discourages an equal division of housework. Governments, though, can influence these outcomes: despite a quite rigid labor market, Scandinavian countries, for instance, have a very high participation rate because of a large and feminized public sector.

Another interesting idea of the book comes in Chapter 4, which discusses fertility. Here the authors start with the much-studied link between fertility and women's labor market participation. In order to increase both participation and fertility, they advocate not more publicly provided child- and eldercare, but subsidies for highly flexible jobs and career interruptions. They argue for these policies because in those countries with 
a labor market unfriendly to women and a low divorce rate (such as, Italy, Greece, and Japan), women fight to enter into the labor market, and they do not have children. They claim that a demonstration effect occurs: women in societies with traditional gender roles imitate women in other societies and enter the labor market, but they give up having children. In their empirical analysis, Iversen and Rosenbluth find that fertility is associated with general-skills occupations and part-time jobs. Fertility is also associated with public spending and employment in the public sector. So, for instance, the US and Sweden have high fertility rates because the US has a labor market based on the availability of generic-skills jobs, and Sweden has more specific-skills jobs but a large public sector. Germany and Japan instead have low fertility rates because it is more difficult for women to find employment in a rigid labor market.

Finally, in the last part of the book, Iversen and Rosenbluth concentrate on two political issues: why women seem more likely to vote for left-wing parties than men, and why women are underrepresented in politics. Using data from twenty-three advanced democracies, Iversen and Rosenbluth conclude, "The possibility of a gender gap in political preferences emerges when marriage contracting is incomplete and termination of the contract is an ever-present possibility. In this case, spouses will have conflicting preferences over who receives family benefits, and they will differ over any policies that affect their outside options" (p. 110). This conflict is not because women will take the outside options, but because such options increase their bargaining power in the household.

Iversen and Rosenbluth also examine the older political gender gap wherein women are more conservative than men. The old gender gap is common in countries where women have limited economic opportunities and thus, fewer outside options and therefore a strong interest in maintaining the sanctity and strength of traditional family values. By contrast, the new gender gap is found in countries with women's high participation in the labor force because left parties are more likely to support policies in favor of public child- and eldercare. Women therefore are more likely to vote for left-wing parties because they can better invest in their marketable skills if they have fewer care and domestic burdens.

Moving on to women's participation in politics, Iversen and Rosenbluth link women's representation here to the specific characteristics required of politicians. The authors argue that women's political careers are easier in those countries where being a politician is a flexible, temporary job than in those countries where a political career means no breaks and full-time work. Majoritarian electoral systems are less favorable to women than proportional systems because in the former, candidates have to develop a long-term tie to their constituents and to other politicians. Men can more readily commit to long and continuous careers, and therefore they are more likely to be elected and reelected. Proportional systems are more 
favorable to women. In their empirical analysis, the authors also find that the representation of women in democratic legislatures is positively influenced by the presence of programmatic parties (as opposed to "candidate-oriented parties" [p. 147]).

What I really find interesting in this book is not only the link between the micro and macro levels of analysis, but also the interdisciplinary approach. The analysis incorporates demographic, economic, political, and sociological perspectives. The authors dare to be ambitious, and they succeed because they do not limit themselves to a restricted field of analysis. This book would be very good reading for international scholars in economics, demography, political science, and sociology. It could also be useful for teaching in general courses on gender studies and specifically for courses in economics of gender, economics of the family, labor economics, or political economy, at the undergraduate or graduate levels.

Here, I come to the only criticisms of this excellent book. Despite the relevance of the research questions for a wide range of countries, the reader quickly realizes that the authors have mainly industrialized countries in mind. And the authors do not provide any explanations or justifications for this choice.

Moreover, I also found myself uneasy in reading about gender inequality and how to change it without questioning the male chauvinist structure of work organization. In fact, the authors support policies to change the labor market (a combination of generating more generic-skills jobs, more flexibility, more public sector, and more service sector) in order to increase women's labor force participation and bargaining power at home and equalize the sharing of housework. But they do not discuss work organization, long paid working hours, the emphasis on attachment to the company, and so on.

Moreover, the causal chain could be reversed: why not start from reforming the division of labor at home, for instance, by introducing compulsory paternity leaves and campaigns for men's involvement in housework? These changes could lead to men's lower participation in the labor market and decrease their relative bargaining power in the household. What about a new book: Men, Work, and Politics?

Lastly, the book assigns a very important role to bargaining models of household decisions, but it takes the theory about bargaining power structure as a given and does not consider the relevant criticism of Amartya Sen (1990) in a feminist perspective. Sen emphasizes that what matters in terms of bargaining power are perceived contributions and perceived interests. In particular, Sen argues that if one person were to attach less value to his or her own well-being, then the solution to the household bargaining process would be less favorable to that person, in terms of wellbeing. Also, if in the accounting of the respective outcomes a person were perceived as making a larger contribution, then the solution would be more 
favorable to that person. In other words, what matters is not only the "real" contribution, but also how that contribution is perceived. Sen's criticism of bargaining theories weakens the authors' suggested causal links between macro- and micro-level variables because these links are justified on the basis of traditional bargaining theories that do not take into account perceived contributions and perceived interests.

\author{
Maria Laura Di Tommaso \\ Department of Economics, University of Torino \\ Via Po 53, Turin 10100, Italy
}

\title{
NOTES
}

${ }^{1}$ Each chapter includes a different selection of industrialized countries: for instance, Chapter 5 analyzes Australia, the UK, Canada, France, Germany, Ireland, Norway, New Zealand, Sweden, and the US. Chapter 4 analyzes Austria, Belgium, the UK, France, Germany, Greece, Ireland, the Netherlands, Norway, Spain, Sweden, Switzerland, and the US.

${ }^{2}$ Simulations based on a sample of seventeen OECD countries from 1870 to 1995. David M. Buss (1989) first carried out this analysis on a different sample of countries.

\section{REFERENCES}

Buss, David M. 1989. "Sex Differences in Human Mate Preferences: Evolutionary Hypothesis Tested in 37 Cultures." Behavioral and Brain Sciences 12(1): 1-14.

Sen, Amartya. 1990. "Gender and Cooperative Conflicts," in Irene Tinker, ed. Persistent Inequalities: Women and World Development, pp. 123-49. New York: Oxford University Press. 